\title{
THE IMPLEMENTATION OF KAIZEN TO IMPROVE AFTER SALES SERVICE IN GENERAL REPAIR (GR) WORKSHOP OF PT NASMOCO KALIGAWE SEMARANG
}

\author{
Muhamad Abdul Ghofur \\ Dian Triyani ${ }^{6}$
}

Faculty of Economics, Semarang University (USM)

\begin{abstract}
This study aims to find out the application of kaizen, the impact felt by the employees in applying kaizen and the customers' feedback on kaizen products that have been implemented to improve the after sales service of PT Nasmoco Kaligawe Semarang general repair workshop.

This study was conducted by using qualitative research method in analyzing the application of kaizen.The method of data collection was carried out by conducting observation and documentation. The data collection method to find out the impact that employees feel and the customers'feedback on kaizen products that have been implemented used the direct interview method with 4 employees who have applied kaizen and 5 customers who have experienced kaizen products.

The results of this study indicate that the application of kaizen in PT Nasmoco Kaligawe Semarang general repair workshop has run well. The impact felt by the employees is also good, the employees become more satisfied at work. The feedback given by the customers for kaizenthat has been conducted is very good. Kaizen makes the customers more comfortable and satisfied with the services provided to themselves and their vehicles.
\end{abstract}

Keywords : Kaizen, employees' satisfaction, customers' satisfaction, service quality.

\section{INTRODUCTION}

The rapid development of the automotive industry in Indonesia has made the level of competition tight, especially in the car industry. The car Brand HolderSole Agent (BHSA) keep performing innovation on their respective products. This can be seen from the increasingly diverse brands and types of cars in Indonesia which have resulted in consumers becoming more selective in choosing which car products to buy. Supported by the development of highly advanced information media, the customers can conductreview of the dream car more deeply and independently.

After getting the dreamed car from the dealer, every consumer wants the condition of their vehicles to be always prime and safe to use. Here, the dealer will get his role back to get profit coffers through the after sales division in the form of maintenance or vehicle maintenance. After Sales division is a fertile field for dealers because it provides all maintenance for the customers' vehicle in the long run, starting after the customers receive the vehicle up to the time of ownership. Not only their vehicles, the vehicle owners must also be given satisfying experience when they are in the after sales area. When the customers are satisfied, the customers will come back to do service retention, repurchase new units, even the customers will recommend the dealer services to others.

Based on studies conducted by J.D. Power Asia Pacific in J.D. Power 2017 Indonesian Customer Service Index (Mass Market) Study, Toyota and Mazda were in the highest rank

6diantriyani@usm.ac.id; Faculty of Economics, Semarang University 
for the after sales service satisfaction level with the acquisition of 744 points. Toyota specifically shows excellent performance in terms of service initiation and service quality. Whereas in the internal study conducted by Toyota Astra Motor (TAM), customer satisfaction levelof Toyota customers nationally in 2017 showed the score of 879 .

It is known that all Toyota dealers apply a culture in their company, this culture is used to solve problems, to make problem solving strategy, to improve the process, to evaluate and to standardize. The culture is kaizen. In Japanese, kaizen means continuous improvement. Kaizen philosophy focuses on the process and way of thinking, in contrast to western concepts that focus on innovation and results. Kaizen is an aspect of gradual change, there are always factors and parts of the process that can be improved (Imai, 1991). In the international world, Kaizen is recognized as a strong strategic instrument for improving productivity, quality, efficiency and security (Titu, Oprean, \& Grecu, 2010). Kaizen doesn't blame people nor eliminate people, but gets rid of things that don't need to be done.

In the current economic condition, we must look for newway which is bolder to achieve goals effectively and efficiently. This is based on the awareness and the fact that our steps in working and daily tasks are not the most effective and efficient steps to be taken. This is the duty of everyone in a company. In workplace such as workshop, continuous improvement is carried out by involving everyone, both managers and workers. Starting from small thing, cheap, avoiding waste, simplifying work, not wasting time, benefiting for the environment and easy to apply. Repairing and improvement made not only focus on increasing productivity in every process that exists, but maintaining the customers' satisfaction is something that should not be forgotten in an automobile repair service industry. Therefore a consistent evaluation must also be made on each process and product to maintain the standards set by the company. The concept of kaizen is implanted in every employees at the dealer. Thus, each employees will be able to do kaizen in their respective work areas. So that kaizen becomes a culture and corporate identity that makes Toyota posesses a good after sales system to build a company and to provide maximum service to the customers.

Unlike companies that use a mediocre work culture in their organizations, they tend to have a lack of understanding between top management and employees at every level in the need to produce constructive suggestions or ideas. A suggestion system that promotes effective communication between management and employees at every levelis very important. This is because the system of improvementsuggestion will encourage employees to contribute their improvement ideas based on the experience they have gained throughout the life they have lived either in the world of work or social life. The success of culture applied and developed in Japan has enabled companies that embrace this culture to experience improvement in the customers' satisfaction, to increaseproductivity indexes, to reach world class standard, to increas the employees' job satisfaction, income and the customers' satisfaction.

From the presentation, the writer was motivated to conduct a study aboutkaizen on aftersales services at an authorized dealer under the auspices of Toyota. The dealer in question is P.T Nasmoco Kaligawe Semarang (Nasmoco Kaligawe) which is the largest Authorized Toyota Dealer in Central Java and Yogyakarta to present times. From this background, the writer took the title, "The Implementation of Kaizento Improve After Sales Servicein General Repair (GR) Workshop of P.T Nasmoco Kaligawe Semarang." Based on the background of the problem described above, the problem formulation can be taken as follows: How is the application of kaizen in increasing the customers' satisfaction in the general repair (GR) workshop of PT Nasmoco Kaligawe Semarangafter sales? 


\section{LITERATURE REVIEW}

The word kaizen derives from two Japanese words "kai" which means changing and "zen" which means to be better (Palmer, 2001). In Japanese, kaizen means continuous improvement. Kaizen philosophy focuses on the process and the way of thinking, in contrast to the western concept that focuses on innovation and result. Kaizen is an aspect of gradual changing, there are always factors and parts of the process that can be improved (Imai, 1991). Kaizen emphasizes that the processing stage in the company must be improved so that results can increase (Imai, 1998). In applying kaizen, it is believed that a good process will give good results (Japan Human Relations Association, 1997). In the international world, kaizen is recognized as a strong strategic instrument to improve productivity, quality, efficiency and security (Titu, Oprean, \& Grecu, 2010). This continuous improvement involves the participation of all people in the organization from the top management to the employees at lower levels.

Kaizen is an initiation in response to problems faced by Japanese industries after World War II, such as the limited resources and the difficulties in obtaining raw materials. Therefore, the Japanese companies began to look for the ways to improve their production process by minimizing waste and optimizing process efficiency. Initially the kaizen initiative was led by Toyota manufacturer in their efforts to become global automotive leader who tried to emphasize additional change, low-cost solutions, employee empowerment and organizational development that were continuously enhanced by emphasizing process rather than result (Imai, 1986). The various kaizen activities include Total Quality Management (TQM), customer orientation, robotics, automation, visual control, quality control, suggestionsystem, Quality Control Circle (QCC), workplace discipline, preventive measures, quality improvement, productivity improvementto new product development. Kaizen can be started by realizing that every company has problem. Kaizen solves the problem by forming a corporate culture where everyone can raise their problems freely (Imai, 1998).

Kaizenand managementrelationis very close, in kaizen management has two main functions (Imai, 1998):

1) Maintenance

That is technology maintenance activities, management system and the existing operational standard while keeping this standard through training and discipline with the aim that all employees can comply with standard operating procedure (SOP) that have been set. The existing facilities are not used by all employees in a company, but the facilities related to common interests, the applicable SOP must be known together and adhered to each employee that is directly related to it, so that an accident does not occur. Therefore the role of each persons in the company should support each other to create a culture of consistency in maintenance is not only from speech but also based on the actual actions of each employees.

2) Repair

The activities aimed to raise the existing standard,improving each existing process in stages to achieve the targeted goals.

These two functions are considered as the standard of maintenance and repair. The improvement itself can be divided into kaizen and innovation. Kaizen is a small improvement that takes place continuously, while innovation is a drastic improvement as a result of investing large amounts of resources in technology or equipment. Kaizen emphasizes human effort, morality, communication, training, cooperation, empowerment and self discipline. These approaches are the improvement approach based on low cost common sense (Imai, 1998). 


\section{RESEARCH METHOD}

In this study, the writers used descriptive research typewith qualitative data type. The location of this research was conducted at P.T Nasmoco Kaligawe Semarang, Central Java, after sales division, general repairworkshop, Jalan Raya Kaligawe KM 5 Semarang.

Informants in this study are people who really understand and are directly related to the implementation of kaizen to improve the after sales servicegeneral repairworkshop of P.T Nasmoco Kaligawe Semarang. The informants consisted of the employees and the customers of the after sales general repairof P.T Nasmoco Kaligawe Semarang.

\section{RESULT AND DISCUSSION}

From the results of interviews about how the impact felt by the employees of P.T Nasmoco Kaligawe Semarang after sales general repair (GR) workshop in implementing kaizen is that employees actually know that kaizen is a continuous change or continuous improvement and join in applying kaizen in their respective work areas in the workshop through small group activity (SGA). The changes made of course for the comfort and the safety of each employees and workpiece in each work area. Not only are employees active but workshop management also provides full support to implementkaizen by providing facilities in the form of fund, training, rooms until there are costs that are indeed budgeted for this activity such as for consumption when kaizen sharing activities take place.

There certainly are challenges faced in implementing kaizen. The factors that become the challenges in doing kaizen are motivations that must always be fostered, consistency that must always be monitored and the willingness of each individual to act sincerely for the sake of the progress and the change in a better direction. With the rules that have been mutually agreed upon, the activities can be carried out routinely and consistently. The compact collaboration is absolutely necessary considering that Kaizendone to make work better, more effective and efficient, involves many people in the processfor a long time. Again the process is very valuable learning for each employees to develop and to interact with each other.

The impact felt by employees in conducting kaizengives very much positive change felt. Starting from self-development being better to the feeling of comfort will accumulate in working with people around, so that a sense of respect for people or care for each other with friendsarises. Therefore, there will be solidarity in it. Not only that, kaizen can also be implemented by the employees in daily life in finding problems and finding out the right solution. As a result when the employees are comfortable working, the employees will be loyal to the company and provide good quality service for the customers' satisfaction. This good culture can also be an added value in the eyes of the customers regarding the service in Nasmoco Kaligawe workshop.

Workshop management that always guides and performs supervisory functions, is also very helpful in implementing kaizen in a company. The company also provides spiritual support that all efforts made must be accompanied by a prayer to Allah the Almighty by conducting a routine weekly recitation in the workshop and Friday prayers in congregation each week. When the employees feel satisfied, the services provided to the customers will be even more extraordinary.

From the patterns and concepts above, the variables that arise include:

1. Kaizenand kaizen organization.

2. Perfect SOP delivery.

3. Employees' satisfaction.

4. Employees' loyalty. 
5. Quality service.

6. Customers' satisfaction.

From the results of interviews about how customers' feedbackon kaizen that has been implemented to the general repair (GR) after salesworkshopof P.T Nasmoco Kaligawe Semarang is that good and professional service quality is friendly, fast service, complete facilities and most importantly complaints must be solved properly. Services that have been given by after sales of Nasmoco Kaligawe according to the customers are good, very customer first where customers are very concerned and maintained their comfort starting from booking, accepting, to the delivery. Facilities and quality of service provided by each process are carried out professionally according to the price offered.

Feedback about kaizen or improvement done isvery good for the customers, the customers are greatly helped by the diagnosis staff at reception, details of excavation of complaints are also good until there iskaizen product in the form of customershandling, if there is a complaint, there must be SOP to conduct. Even the customers are also included in the repair process, namely when conducting test drive to ensure complaints and determine whether the complaint has been completely resolved.This is an educational tool for the customers so that the customers also know how the repair process runs every process.It also fosters the customers' trust in the workshop. The kaizen product that has been felt by the customers is a differentiation that becomes a separate selling value for the customers. Customers who are satisfied with after sales service ofNasmoco Kaligawe, will conduct service retention for future service. Of course this will greatly help company to get more profits. Not only that, the customers will also recommend after sales services ofNasmoco Kaligawe to the others. This is also an advantage for Nasmoco, because word of mouth from the customers will make Nasmoco Kaligawe better known and become service reference for more customers.

From the patterns and concepts above, the variables that arise include:

1. Kaizen.

2. Service quality.

3. Customers' satisfaction.

4. Customers' loyalty.

5. Customers' retention.

6. Customers' recommendation.

Based on the categorization of data that patterns and conceptshave been identified from the results of interviews with the employees and the customers who are directly involved in the implementation of kaizen, the following variables are found.

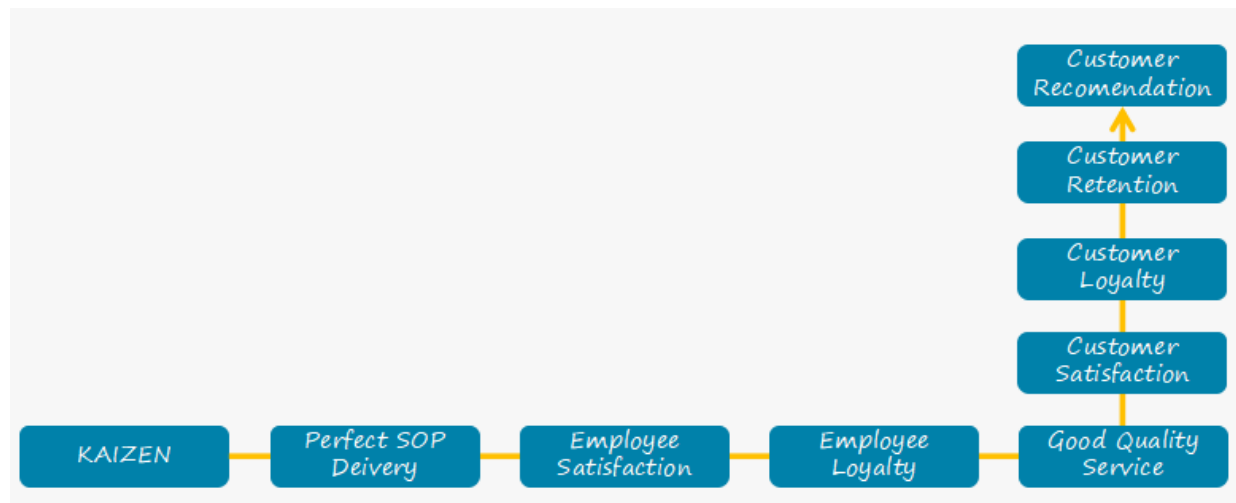


1. Kaizen and kaizen organization.

2. Perfect SOP delivery.

3. Employees' satisfaction.

4. Employees' loyalty.

5. Quality of service.

6. Customers' satisfaction.

7. Customes's loyalty.

8. Retention / repurchase.

9. Customers' Recommendation.

\section{CONCLUSION}

Based on a series of studies that have been conducted, observation and dataprocessing as well as the results of data analysis that refers to the problem and purpose of the study, it can be concluded that:

1. The kaizenimplementation with the concept of Toyota Business Practice (TBP) to improve the after sales service in the GRworkshop of P.T Nasmoco Kaligawe Semarang has been going well. The kaizen products that have been implemented can improve the after-sales service.

2. When working conditions is more secure and comfortable, the employees will be satisfied and happy while working, so that loyalty will grow. The employees' loyalty will form good teamwork and increase the employees' awareness of kaizenimplemented in the company, so that the service will be better to provide maximum satisfaction for the customers.

3. When the customers are satisfied with the after sales service provided, the customers surely will do retention. In addition to doing retention, the customers will recommend the services to the others.

\section{RESEARCH LIMITATION}

This study still has several limitations that can be taken into account by the future researchers. Some limitations of the study include:

1. The object of research is still limited only to the general repair (GR) workshop of P.T Nasmoco Kaligawe Semarang in Central Java, while in Indonesia there are still many Toyota dealers with various kinds of kaizen with various problems in geographical and demographic conditions that are different one from another.

2. Some conditions when conducting interviews, the researchers felt a little implicit meaning that there were some things considered biased, but that could be solved by cross checkingwith other informants and also actual check of the real conditions in the field during the observation.

\section{SUGGESTION}

Based on the results of the analysis and the conclusions obtained, the suggestions that can be proposed, either for the general repair (GR) workshop of P.T Nasmoco Kaligawe Semarang or further researches, are:

1) Evaluation of the problems must be carried out continuously for the development of the company.

2) The kaizen products that have been implemented must be carried out consistently by all employees. 
3) It is very important for the company leaders and all employees to continuously monitor the flow of the process or the activities of each company staff so that the sustainability of the company with all its success in achieving goals is maintained.

\section{BIBLIOGRAPHY}

Bodgan, Robert and Biklen.(1992). Qualitative research for education and introduction to theory and methods. Boston: Allyn and Bocon.inc

Dharmmesta, B.S. .(1999). Loyalitas Pelanggan: Sebuah Kajian Konseptual Sebagai Panduan Bagi Penalty, Jurnal Ekonomi dan Bisnis Indonesia, Vol. 14, No. 3. Pp. 73-88.

Edilius dan Sudarsono.(1994). ManajemenKoperasi Indonesia. Jakarta : Rineka Cipta

Garcia-Sabater, J.J., \& Marin-Garcia, J.A. (2011). Can we still talk about continuous improvement? Rethinking enablers and inhibitors for successful implementation. International Journal Technology Management, 55, 28-42.

Hani, T. H. (2001). Manajemen Personalia dan Sumber Daya Manusia. Yogyakarta : BPFE.

Hasibuan, Malayu.(2006). Manajemen Dasar, Pengertian, dan Masalah. Jakarta : Bumi Aksara.

Hasibuan, M.S.P. (2001). Manajemen sumber daya manusia.Jakarta : BumiAksara.

H.B. Sutopo.(2002). Pengantar penelitian Kualitatif. Surakarta: Universitas Sebelas Maret.

H.B. Sutopo.(2006). Metodologi Penelitian Kualitatif : Dasar Teori dan Terapannya dalam Penelitian. Surakarta: Universitas Sebelas Maret

Hitoshi Takeda.(2006). The Synchronized Production System : Going Beyond Just in-Time Through Kaizen. London : Kogan Page London and Philadephia.

Imai, M. (1986). Kaizen: The Key to Japan's Competitive Success. New York: McGraw-Hill.

Imai, Masaaki. (1991). Kaizen : The Key to Japan's Competitive Success. Singapore : McGraw- Hill International.

Imai, Masaaki. (1998). Genba Kaizen : Pendekatan Akal Sehat, Berbiaya Rendah Pada Manajemen. Jakarta : Pustaka Brinaman Pressindo.

Imai, Masaaki \& Brian Heymans.(2000). Collaborating for Change: Gemba Kaizen. San Francisco : Berrett-Koehler Publishers. Singapore : McGraw-Hill International.

Japan Human Relations Association.(1997). Kaizen Teian 1 : Developing Systems for Continuous Improvement Through Employee Suggestions. New York : Productivity Press.

Japan Human Relations Association. (1997). Kaizen Teian 2 : Guiding Continuous Improvement Through Employee Suggestions. New York : Productivity Press. 
K, D., II, S., \& Smalley, A. (2008). Understanding A3 Thinking: A

CriticalComponent of Toyota's PDCA Management System. New York, NY:Productivity Press.

Kotler, P. .(2000). Marketing Management, The Millenium Edition. New Jersey : Prentice Hall International, Inc.

Liker, J. K. (2006). The Toyota Way. Jakarta : Erlangga.

Mangkunegara, Anwar. (2006). Manajemen Sumber Daya Manusia.Bandung : Remaja Rosdakarya.

Mowen, J.C. dan M. Minor.(1998).Consumer Behavior, 5th Ed. Upper Saddle River. NJ: Prentice Hall,Inc.

Ohno, Taiichi (1998). Toyota Production System.Productivity Press. Hlm. 8. ISBN 0915299.14-3

Palmer,V.S. (2001). Inventory Management Kaizen. Proceedings of $2^{\text {nd }}$ International Workshop on Engineering Management for Applied Technology, Austin, USA. 55-56.

Pullin, J.(2005).Room for improvement.Professional Engineering, 18(15), 3 138.

Rangkuti, Freddy.(2002). Measuring Customer Satisfaction (CetakanKetiga). Jakarta: PT Gramedia Pustaka Utama.

Robinson, A.G., \& Schroeder, D.M. (2004). Ideas are free: How the idea revolution is liberating people and transforming organizations. USA : BerrettKoehler Publishers.

Sumakmur.(1993). Keselamtan dan Pencegahan Kecelakaan. Jakarta: Haji Masagung.

Titu, M. A., Oprean, C., \& Grecu, D. (2010). Applying the Kaizen Method and the 5S Technique in the Activity of Post-sale Services in the Knowledge-based Organization. Proceedings of the International Multi Conference of Engineers and Computer Scientists, 3, pp. 1-5.

Tjiptono,Fandy.(1997).Strategi Pemasaran, Edisi 1.Yogyakarta: Andi.

Tjiptono, Fandy.(2000). Manajemen jasa, Edisi Pertama. Yogyakarta: Andi Offset.

Tjiptono, Fandy.(2008). Strategi Bisnis Pemasaran. Yogyakarta: Andi.

Wescott, R. (2005). The Certified Manager of Quality / Organizational Excellence Handbook (3rd ed.). Milwaukee, WI : Quality Pre 
